\title{
Passive potential affixation: syntax or lexicon?
}

\author{
Anikó Lipták \\ Leiden University \\ A.Liptak@hum.leidenuniv.nl \\ István Kenesei \\ Research Institute for Linguistics, Hungarian \\ Academy of Sciences and University of Szeged \\ kenesei.istvan@nytud.mta.hu
}

\begin{abstract}
In this paper we will argue that contrary to the received view passive potential affixation in Hungarian primarily derives complex syntactic objects rather than adjectives. By means of a number of tests we show the differences between the two classes of items bearing the homophonous affix -ható/hetó: one a nonfinite verb form, the other a lexicalized adjective. In addition to a syntactic analysis of this composite affix, a typology is provided for languages that have similar constructions.
\end{abstract}

Keywords: -ható/hetö; affixation; nonfinite clause; participle

\section{Introduction}

In this paper we will argue that contrary to the received view, passive potential affixation primarily derives complex syntactic objects rather than adjectives. Our arguments are mainly based on Hungarian data but in our final analysis we rely on constructions from a number of unrelated languages, such as Turkish, Japanese, and Chichewa, and to a lesser degree, Russian. We will challenge the view that the equivalent of English -able affixation as in the derived form acceptable, the Hungarian affix -ható/hetö derives adjectives from passivized verbal roots.

Instead, we will propose that productive passive potential affixation derives nonfinite verb forms from transitive verbs, which differ from homologous adjectives in a number of syntactic, morphological, and morphophonological criteria, including the possibility of modification, the availability of comparative forms, retaining the verb's argument structure, among other things. Since the adjectives in this class are all lexicalized, we will argue that there is a bifurcation of functions: adjectives are in the lexicon, primarily because of the behavior of verbal particles, which are 
inseparable in the adjectives, while nonfinite verb forms are a result of a syntactic process. As will be shown, it is the data that forces us to follow a weakly lexicalist hypothesis in this paper.

Again in contrast with previous research we will claim that the affix in question can be analyzed into overt potential and participial constituents, and a covert passive one, as supported by related constructions in other languages, which allows us to put forward a typology in which some or another of these constituents can be overt or covert.

The paper is structured as follows. In section 2, we address the issue of the category of the affix using cross-linguistically valid syntactic and morphological criteria defining adjectives, and distinguish the lexical objects from the syntactic ones. Section 3 is dedicated to syntactic tests, with the help of which we demonstrate that the clausal forms, when based on a verb with a preverbal particle, have subparts that are syntactically autonomous in certain contexts. In section 4 , we turn to a language-specific morphophonological distinction between lexicalized adjectives and syntactically formed nonfinite clauses that is attested in the presence or absence of the linking vowel before the plural marker. Section 5 presents our analysis of the two types of constructions, including a syntactic structure of passive potential clauses. It concludes with a typology of passive and potential affixation of similar constructions in a few other languages. Section 6 provides a summary of the findings.

\section{Differentiating between adjectival and non-adjectival ható forms}

The ható affix productively attaches to transitive verbs, and the resulting ható forms can be used both attributively and predicatively. (1) illustrates this for érthetố 'understandable', containing a transitive verb and (2) for the case of the ditransitive adható 'givable', which obligatorily occurs with a direct and an indirect object argument, the latter being gyerekeknek 'to children' in $(2) .{ }^{1}$

${ }^{1}$ Note that -ható is realized as -ható or -hetố depending on vowel harmony exhibited with the stem, so technically it should be represented as $-h A t O ́$. For ease of exposition we refer to the affix throughout simply as ható. In the glossing of ható words we diverge from spelling conventions and separate the preverb and the verb stem when they are syntactically autonomous and do not form one lexical item. Specific abbreviations used in this article are: $\mathrm{AOR}=$ aorist; $\mathrm{COMP}=$ comparative suffix; $\mathrm{INE}=$ inessive; $\mathrm{ELA}=$ elative $\mathrm{MOD}=$ modality $\mathrm{OBL}=$ modal affix expressing obligation $; \mathrm{POT}=$ potentiality; $\mathrm{DEF} / \mathrm{INDEF}=$ definite $/$ indefinite conjugation $; \mathrm{PASS}=$ passive $;$ PASS.PRT $=$ pas- 
(1) a. egy ért-hetô szöveg

an understand-ABLE text

'an understandable text'

b. Ez a szöveg ért-hető.

this the text understand-ABLE

'This text is understandable.'

(2) a. a gyerekeknek nem ad-ható könyvek

the children.DAT not give-ABLE book.PL

'the books that cannot be given to children'

b. Ezek a könyvek nem ad-ható-k gyerekeknek. these the book.PL not give-ABLE-PL children.DAT

'These books cannot be given to children.'

As it turns out when considering other properties of these ható forms, their uniform usage as attributive and predicative modifiers does not entail identical categorial status in the two cases: simplex ható forms like érthetố 'understandable' differ from complex ones that retain their source verb's argument structure, such as adható 'givable' in (2).

The difference between these two types is observable if we subject simplex and complex ható forms to morphosyntactic tests that are used to identify adjectives. The criteria we will use for this purpose, following Komlósy (1992), are:

(i) modification by intensifiers

(ii) serving as possible input to lexical derivations

(iii) the availability of comparative forms

As the rest of this section will show, the application of these three tests yields the result that there are two distinct classes of hato forms: those that pattern as ordinary true adjectives (cf. érthetô) and those that do not (cf. adható). We will also show that this difference aligns with other differences: the ható forms' ability to retain their base verb's argument and event structure, as well as differences concerning their interpretation.

sive participle; PR.PRT $=$ present participle; $\mathrm{PART}=$ verbal particle $; \mathrm{SUB}=$ sublative; SUP $=$ superlative prefix. 


\subsection{Testing for the adjectival category}

Let us then go through the above three tests one by one. The first test that differentiates between the two types is modification by intensifiers, such as kifejezetten 'particularly', or nagyon 'very'. These intensifiers are perfectly fine when modifying ordinary adjectives in Hungarian (3), and can also precede ható forms like (4), but not those in (5). In the latter case, a meaning similar to the intended one can only be expressed using adverbial modifiers such as jól 'easily':

(3) egy kifejezetten/ nagyon hosszú szöveg

a particularly very long text

'a particularly/very long text'

(4) egy kifejezetten/ nagyon ért-hető szöveg

a particularly very understand-ABLE text

'particularly/very understandable text'

(5) a problémára \{*kifejezetten/*nagyon/ jól\} alkalmaz-ható megoldás the problem.SuB particularly very well apply-ABLE solution lit. 'the solution particularly/very/well applicable to the problem'

This shows that the form in (4) is categorically an adjective, while the one in (5) is not.

The second test concerns serving as possible input for derivational processes that apply to adjectives. Words like érthetô 'understandable' or beszámitható 'sane' test positively in this respect: they can be input to lexical derivations which operate on adjectives, such as nominalizations or adverb formation, see the examples in (6). Items like leültethetó 'seatable' or adható 'givable' do not give rise to such derivatives, cf. (7):
(6) ért-hetô-ség
understand-ABLE-NOM
'understandability'
ért-hető-en
understand-ABLE-ADV
'understandably'
beszámít-ható-ság
PART.count-ABLE-NOM
'being sane'
beszámít-ható-an
PART.count-ABLE-ADV 'in a sane manner'
(7) *leültet-hető-ség
PART.seat-ABLE-NOM
lit. 'seatability'
*leültet-hetô-en
PART.seat-ABLE-ADV
lit. 'in a seatable manner'
*ad-ható-ság
give-ABLE-NOM
lit. 'givability'
*ad-ható-an
give-ABLE-ADV
lit. 'in a givable manner' 
Third, érthetố 'understandable' or beszámítható 'sane' also pattern alike and unlike complex ható forms in that they have morphological comparative forms, just like ordinary, underived adjectives in Hungarian:

(8) az \{́rt-hető-bb/ leg-ért-hetô-bb\} szövegek the understand-ABLE-COMP SUP-understand-ABLE-COMP texts 'the more understandable/most understandable texts'

(9) a \{beszámít-ható-bb/ leg-beszámít-ható-bb\} emberek the PART.count-ABLE-COMP SUP-PART.count-ABLE-COMP people 'the more/most sane people'

leültethetô 'seatable' or akasztható 'hangable', on the other hand, do not have comparative forms, as (10) shows (see also Farkas 2013, for a similar observation).

(10) a. *Öt ember leültet-hetô-bb, mint tíz.

five man seat-ABLE-COMP than ten

(intended meaning: 'Five people can be better/easier seated than ten.')

b. ${ }^{*} \mathrm{Ez}$ a kabát fogasra akaszt-ható-bb (mint az).

this the coat rack.SUB hang-ABLE-COMP than that

(intended meaning: 'This coat can be hung onto racks better than that one.')

Note that the ungrammaticality of the example in (10b) is not due to the presence of the overt argument, as overt arguments do not block the comparative form in the case of ordinary adjectives (11):

(11) Ez az apa büszké-bb a fiára, mint az.

this the father proud-COMP the son.POSS.3SG.SUB than that

'This father is more proud of his son than that one.'

This set of three criteria reviewed above clearly singles out some forms derived by means of ható as true adjectives, and others as non-adjectival.

\subsection{Differences in argument and event structure and interpretation/compositionality}

The non-adjectival type of ható forms are distinct from the adjectival ones when it comes to yet another aspect as well. Obligatory internal arguments of the base verb are required to appear next to the ható form, without these such ható forms cannot be used, they are ungrammatical, cf. (12b). The 
agent is also expressable; it can appear optionally and is always marked by által 'by', cf. (13).

(12) a. A könyvtáros könyveket ad az olvasóknak. the librarian books.ACC give.3SG the readers.DAT 'The librarian gives books to the readers.'

b. (a könyvtáros által) az *(olvasóknak) ad-ható könyvek the librarian by the readers.DAT give-ABLE books 'the books that can be given to readers by the librarian'

(13) a. Mindenki letölti ezt a programot. everyone download.3SG this.ACC the program.ACC 'Everyone downloads this program.'

b. Ez a program (bárki által) letölt-hető. this the program anyone by download-ABLE 'This program can be downloaded by anyone.'

The agent of a causativized verb, namely the causee, can also be optionally retained similarly to agents of simple transitive verbs. Note that the case (instrumental) is retained on the causee:

(14) a. A zenetanár elénekel-tet-i a gyerekekkel a dalokat. the music.teacher PART.sing-CAUS-3SG the children.INST the songs.ACC 'The music teacher makes the children sing the songs.'

b. (a gyerekekkel) elénekel-tet-hetó dalok the children.INST PART.sing-CAUS-ABLE songs 'songs that the children can be made sing'

Similarly to retaining the base verb's argument structure, non-adjectival ható forms inherit their base verb's event structure as well. For example, these forms can appear together with adverbs that modify the event, as in (15a-b), where helyben 'on the spot' and többször 'more than once' modify the waiting and the printing event and not the ability to wait for or print something. (15a) also shows that temporal modifiers that occur with the ható form matches the type of the base predicate: megvárható 'PART.wait.ABLE' can be modified by in 2 hours just like meg-vár 'PARTwait' can.

(15) a. az eredmény \{helyben/ 2 óra alatt $\}$ megvár-ható the result place.INE 2 hour under PART.wait-ABLE 'you can wait for the result on the spot/in 2 hours' 
b. egy e-jegy többször nyomtat-ható

an e-ticket more.times print-ABLE

'an e-ticket is printable more than once'

Adjectival ható forms, on the other hand, unlike non-adjectival ható forms, do not inherit their verb's argument and event structure, such that the arguments of the original base verb cannot be added to them (cf. (16a,b)).

(16) a. (*Mari által) beszámít-ható emberek

Mari by PART.count-ABLE people

'people who are sane (*to/for/by Mari)'

b. (*mindenki által) ért-hetô-bb szövegek

everyone by understand-ABLE-COMP texts

'texts more understandable (*by everyone)'

In (16b), we are using the comparative form of érthetô" 'understandable', to disambiguate it in its adjectival use, as this word is ambiguous between the two uses: the same form can also have a non-adjectival use, when it combines with a subject $b y$-phrase. In the latter use it counts as a non-adjectival form of ható, and the comparative morpheme is impossible: ${ }^{2}$
mindenki által ért-hető(*-bb)
szövegek
everyone by understand-ABLE-COMP texts
'texts (more) understandable by everyone'

The ambiguity described here characterizes many other forms as well, such as értékelhetố 'appreciable/can be evaluated', áttekinthetô' 'transparent/can be (re)viewed', elérhetố 'available/can be reached', megbizható 'trustable/can be entrusted (with a task)', tưrhetố 'passable/can be endured'.

${ }^{2}$ Note that adjectival ható can combine with experiencers, but these are not arguments of the source verb but optional experiencers. This is demonstrated by the fact that they must appear with dative case, differently from the agent arguments of non-adjectival ható forms that are marked by által 'by' (ia). Dative case marked experiencers are available in combination of adjectival predicates as well, compare (ib).

(i) a. Ez a szöveg mindenkinek ért-hető-bb, mint az. this the text everyone.DAT understand-ABLE-COMP than that 'This texts is more understandable to/for everyone than that.'

b. Ez a szöveg mindenkinek hosszú. this the text everyone.DAT long 'This texts is long to/for everyone.' 
(18) a. adjectival form

Péter próbálkozása értékel-hetô.

Péter attempt.POSs.3sG evaluate-ABLE

'Péter's attempt is appreciable.'

b. non-adjectival form

A versenyzők teljesítménye 10-pontos skálán értékel-hetô.

the competitors' production.POSs.3SG 10-point scale.SUPER evaluate-ABLE

'The competitors' production can be evaluated on a 10-point scale.'

As the translations show, the adjectival and the non-adjectival forms differ in some aspects of meaning. While the non-adjectival form is fully compositional, the adjectival form may have a shifted, non-compositional meaning that is not predictable from the meaning of the base verb. Nonpredictable meanings are illustrated in the following examples: beszámitható 'PART.count-ABLE' contains the verb számit 'count (on)', but instead of meaning 'countable on', it means 'sane'; vár-ható 'wait-ABLE' containing vár 'wait', has a shifted meaning corresponding to 'expected'.

(19) a. beszámít-ható emberek

PART.count-ABLE people

'sane people'

b. Vár-ható, hogy a csapadék eloszlása egyenetlenebb lesz. wait-ABLE that the rainfall distribution.POSS.3SG uneven.COMP be.FUT 'It is expected that the distribution of rainfall will be more uneven.'

\subsubsection{The key distinction: ható adjectives and ható clauses}

The category difference as well as the differences in the presence/absence of argument and event structure point to the conclusion that there are two types of ható forms in Hungarian (see also Komlósy 1992 for the same conclusion). One group is ható forms that are lexical adjectives and which lack an argument and event structure associated with their base verb. The other type is non-adjectival concerning its category and retains the base verb's event and argument structure, which is indicative of a verbal projection that contains these arguments. In line with this, we claim that this second group of ható forms are nonfinite, i.e., participial clauses, which can function as prenominal modifiers or as main predicates in a sentence. These participial clauses are formed in the syntax by applying ható to a verbal projection (for details, see section 5 below). Given that these clauses are productively derived in the syntax, under our analysis ható is an inflectional affix, similarly to affixes yielding other participial forms 
in Hungarian, such as -ó/ő deriving present participles or $-t / t t$ deriving passive (traditionally called past) participles, see, among others, Laczkó (2000; 2001; 2008).

Concerning the truly adjectival class of ható forms, we believe that these correspond to lexicalized instances of ható participles that through frequency of use acquire the adjectival category and get listed as lexical items of Hungarian. We use the term lexicalization here in its widely accepted meaning, as a process of change whereby speakers use a linguistic form with formal and semantic properties that are not completely derivable from its components (see Traugott \& Dasher 2002; Brinton \& Traugott 2005, also Bauer 1983). We claim that the adjectival nature of ható adjectives is brought about by the lexicalization process, as an instance of formal change affecting category. In addition to this kind of formal change, ható participles - similarly to other participles in Hungarian - also lose their complement frames, i.e., their ability to take arguments (see Komlósy 1992; 1994; H. Tóth (2000) for the same point).

There are two reasons why the process of lexicalization can account for ható adjectives better than lexical word formation. One has to do with productivity: unlike ható clauses that are without exception productively derived from a transitive verb phrase, ${ }^{3}$ ható adjectives are the result of a rather unproductive process, as many potentially possible forms do not occur in the language (Table 1, overleaf).

Second, as (19) has illustrated, unlike ható participles, whose meanings are always fully compositional, ható adjectives often have unpredictable, non-compositional meanings that are not derived from the meanings of their base verbs. These facts are predicted if ható adjectives are lexicalized forms, and their idiomatization is due to the lexicalization process. In this respect, ható forms are analogous to other participial clauses; lexicalized present participles like kitün-ô 'outstand-PR.PRT; outstanding, excellent' or borzaszt-ó 'horrify-PR.PRT; horrible', whose meanings are obscured in comparison to their original compositional meanings as participial forms.

It is important to note that compositionality is not the only aspect of meaning that can differentiate between adjectival and non-adjectival ható forms. Often one can find a distinction in interpretation when it comes to the stage vs. individual level readings. While ható clauses express stage

${ }^{3}$ In a few exceptional cases the ható adjective does not even correspond to a transitive verb, cf. él-hetố 'live-able', lit. a place where you can live nicely; ég-hetô 'burn intrable; flammable'. If ható adjectives all originate from syntactic ható forms, as we argue here, exceptions like these should not occur in large numbers. This is exactly what we find, ható adjectives with intransitive verbs are sporadic. 
Table 1:

\begin{tabular}{llll}
\hline & Form & Gloss & Translation \\
\hline \multirow{2}{*}{$\begin{array}{l}\text { Existing } \\
\text { ható }\end{array}$} & áttekint-hetô & overview-able & overseeable \\
adjectives & elvisel-hető & reach-able & reachable \\
& hozzáfér-hető & bear-able & bearable \\
& köz-ért-hető & access-able & available \\
& tür-hetô & bear-ablic-understand-able & understandable by all \\
Non-existing & $*$ ismer-hető (emberek) & know-able & passable \\
\cline { 2 - 2 } & $*$ ve-hető (áruk) & buy-able & (people who) can be known \\
adjectives & $*$ leültet-hető (emberek) & seat-able & buyable (products) \\
& $*$ felad-ható (probléma) & give.up-able & (people who) can be seated \\
& & & (problem that) can be given up \\
\hline
\end{tabular}

level predicates, ható adjectives have individual level readings, as adjectives usually denote inherent properties. To illustrate, consider the case of megbizható 'trustable'. As an adjective, without any modifiers indicating temporal boundedness, it is used to express someone's permanent characteristic (cf. 20a), as a ható clause, on the other hand, it expresses its subject's temporary, transient property in (20b), in line with the fact that the participial clause is temporally anchored:

(20) a. individual level predicate

János megbíz-ható(-bb mint Mari).

János PART.trust-ABLE(-COMP than Mari)

'János is (more) trustable (than Mari).'

b. stage level predicate

János ma meg-bíz-ható ezzel a feladattal.

János today PART-entrust-ABLE this.INST the task.INST

'János can be entrusted with this task today.'

This tendency, however, does not mean that ható adjectives cannot be used with a stage level interpretation: they can also be used as predicates that are temporarily bound, as (21) illustrates (both examples from the internet). ${ }^{4}$

(21) a. Ausztria pénzügyi rendszere sebez-hető-bb, mint volt.

Austria financial system.POSS.3SG wound-ABLE-COMP than was

'Austria's financial system is more vulnerable than it was.'

${ }^{4}$ Sources: (21a): https://tinyurl.com/j44292f; (21b): https://tinyurl.com/zhnu95h (last accessed 15-01-2017). 
b. Addig ugyanis bár már nálam lakott, még beszámít-ható then.TILL namely although already ADE.1SG lived.3SG yet PART.count-ABLE volt. was 'Till then, although he already lived with me, he was still sane.'

In sum, this section has identified two classes of ható forms that differ from each other in various respects. Using a set of criteria that can identify categorial status as well as phrase vs. word-level distinctions, we have established that only lexical ható forms are true adjectives, while ható clauses are participial clauses (see Kenesei 1996; 2014, for the application of these criteria to related phenomena). The properties of each type are summarized in Table 2.

Table 2: Properties of the two classes of ható forms

\begin{tabular}{|c|c|c|}
\hline Properties of ható forms & ható adjectives & ható clauses \\
\hline modification by intensifiers or adverbs & intensifiers & adverbs \\
\hline input to lexical derivations & $\checkmark$ & $*$ \\
\hline availability of comparative forms & $\checkmark$ & * \\
\hline non-compositional meaning possible & $\checkmark$ & * \\
\hline argument and event structure preserved & $*$ & $\checkmark$ \\
\hline (vi) interpretation & stage/individual level & stage level \\
\hline
\end{tabular}

We hasten to add that while our findings hold for the specific case of ható in Hungarian, we are by no means the first to propose that -able-affixation is not uniform in languages. We are aware of proposals for other languages that suggest that -able forms can be classified into two classes, according to syntactic, morphological and semantic criteria.

Concerning category distinctions, Leeman (1992) has identified some -ble forms in French as belonging to either a 'verbal' or an 'adjectival' category. Verbal -ble can be modified by an event adverb, but adjectival -ble cannot (see (22)). Also, verbal forms are paraphrasable by the verbal predicate in question, while adjectival forms are not paraphrasable by the original verb (cf. (23)). This distinction is similar to what we are making between clausal and adjectival ható.

(22) a. une manette qui est abaissable rapidement

(verbal -ble form)

a lever that is lowerable quickly

'a lever that is quickly lowerable' 
b. *un homme qui est abominable rapidement

(adjectival -ble form)

a man who is horrible quickly

'a man who is (*quickly) horrible'

(23) a. La manette ne paraît pas abaissable mais j'y arriverai quand même. the lever NE seems not lowerable but I in-it will.succeed anyway 'The lever does not seem lowerable, but I will succeed anyway.'

b. un prix abordable $\quad={ }^{? ?}$ un prix qu'on peut aborder

a price reasonable/affordable a price that one can reach

A similar distinction has also been recognized in English, where -able gives rise to both productive and non-productive forms. Fabb (1984) argues that the non-productive ones (which can also be based on intransitive verbs or nominals, cf. examples in $(24 a, b))$, are derived in the lexicon, and necessarily do not associate with arguments. Productively derived ones, on the other hand, are formed in the syntax and retain, among other things, secondary predicates.

(24) a. perishable; variable

(non-productive -able)

b. palatable, objectionable, comfortable, seasonable

c. ${ }^{*}$ it is flammable to ashes

d. *he is risible out of the room

(25)
a. rememberable, conquerable, wearable
(productive -able)
b. Beef is eatable raw./Trout is hammerable flat.

Our own account of Hungarian ható sides with Fabb (1984) in that we also propose that ható can apply in the syntax, but we go further in that we claim it always does so in fact (recall footnote 3 above about intransitive forms in Hungarian). This way, via putting down the adjectival cases of ható to a lexicalization process, we arrive at the simplest theory. ${ }^{5}$

${ }^{5}$ At this point the reader might wonder why we do not adopt a non-lexicalist model like Distributed Morphology (DM) (Halle \& Marantz 1993) for our analysis, instead of the weakly lexicalist approach to word formation we follow. DM subscribes to the view that all types of word formation take place in the syntactic component, and there is no stored list of the output of word formation corresponding to a single Lexicon. Consequently, in this framework no distinction can be made between syntactic word formation vs. forms that are lexicalized outputs of syntactic word formation. To explain the differences between adjectival ható and ható clauses in this framework, we would need to postulate a difference in the height of attachment of (what makes up) the ható ending in the two cases, with reference to the standard DM practice 
In the rest of the paper, we return to the characterization of the properties of the Hungarian ható affix and provide further, language-specific evidence for a syntactic versus lexical status of the two forms. Section 3 is dedicated to their distinct syntactic behavior with respect to the position of verbal particles. Section 4 shows that the two trigger a difference in the realization of the plural marker they take. Section 5 provides the outline of our syntactic analysis of ható participles in Hungarian, as well as our proposal for treating the phenomena of passive potential affixation in other languages.

\section{Further syntactic differences between adjectival and clausal ható forms: verbal particle position}

The present section furnishes independent support for the differentiation above between adjectival and participial occurrences of ható. The evidence to be presented comes from the realm of syntax and concerns the syntactic behavior of verbal particles in the two classes of ható we established above.

Many Hungarian verbs combine with so-called verbal particles (abbreviated as PART), which occur with the verb and have aspectual or predicative roles, often resulting in idiosyncratic combinations with the verb. As argued in several recent works (e.g., Koopman \& Szabolcsi 2000; Surányi 2009a;b), verbal particles are phrasal constituents, which furthermore do not form a single lexical item with the host verb. Rather, the verb and

to differentiate "inner" (low, root-) affixation for the case of ható adjectives, yielding non-predictable meaning vs. "outer" (high) affixation for ható clauses, yielding predictable, regular meaning (see Anagnostopoulou \& Samioti 2014; Wood \& Sigurðsson 2014; Oltra-Massuet 2014 for proposals along these lines to -able affixation in other languages).

The reason why we do not adopt this approach to our data is twofold. One reason is that we are aware of one ható adjective in which ható attaches high enough to qualify as an outer affix, yet the form is clearly adjectival: the case of el-számol-tatható-(bb) PART-count-CAUSE-ABLE-(COMP) 'can be made accountable', in which ható follows the causative -tat morpheme, an outer affix (see the discussion of this element in Bartos 2011). Since the position of ható should be higher than that of causative -tat, we predict that this form can only be a ható participial (see also ex. (14) above), contrary to the finding that elszámoltatható has comparative forms and thus is of the adjectival category. The occurrence of this item is not predicted by an inner affixation account to ható adjectives, but can be explained if these forms are lexicalized participial ható forms. A second reason why we do not follow DM for the analysis of our data is because at this point, it is not clear to us how DM could handle the patterns in section 3 (see below), where Lexical Integrity (a notion lacking in DM) forms a crucial part of our argument. 
its particle are generated in two distinct positions in the syntactic structure and the particle reaches its immediately preverbal position in neutral clauses via movement. Even though the exact details of the derivation are immaterial for the present purposes, we take the verb to be in $\mathrm{T}$ and the particles to occupy Spec,TP in neutral clauses (following Kenesei 1989; Surányi 2009b, among others).

Importantly, the position immediately left of the verb is not the only position available to particles. Particles show a large degree of syntactic independence from the verb in all finite and some nonfinite clauses in contexts that contain focus or sentential negation. In these contexts the particle is stranded by the verb moving higher and as a result may appear at a distance following, rather than preceding the verb. Consider the position of meg, the perfectivizer particle with respect to its host verb biz 'have trust in' in the following examples. ${ }^{6}$

(26) a. neutral clause: PART - V order

Jánost meg bíztam ma a feladattal.

János.ACC PART entrusted.1SG today the task.INST

'I entrusted János with the task today.'

b. clause with focus: V...PART order

JÁNOST bíztam ma meg a feladattal.

János.ACC entrusted.1SG today PART the task.INST

'It was János who I entrusted with the task today.'

c. clause with negation: V...PART order

Jánost nem bíztam ma meg a feladattal.

János.ACC not entrusted.1SG today PART the task.INST

'I did not entrust János with the task today.'

Leaving irrelevant syntactic details aside, the crucial observation for us is that the kind of syntactic position attested in (26) also characterizes ható participles. When the verb affixed by ható functions as the main predicate of the clause, it must strand its particle if the sentence contains focus or sentential negation (the non-stranded versions, not illustrated here for reasons of space, are ungrammatical; see also Farkas 2013):

${ }^{6}$ The verb biz 'have trust in someone' differs both in its complement/argument structure and thematic frame from the PART - V combination meg biz 'entrust/commission someone with something', the former intransitive with an experiencer external argument, while the latter transitive with an agentive one. Focus is marked by small caps. 
(27) a. János meg bíz-ható ma a feladattal.

János PART entrust-ABLE today the task.INST

'János can be entrusted with the task today.'

b. JÁNos bíz-ható ma meg a feladattal.

János entrust-ABLE today PART the task.INST

'It is János who can be entrusted with the task today.'

c. János nem bíz-ható ma meg a feladattal.

János not entrust-ABLE today PART the task.INST

'János cannot be entrusted today with the task.'

On the other hand, ható adjectives do not allow for such particle placement, in fact particles can never occur in non-adjacent position with respect to the host verb: in the cases of ható adjectives, the particle cannot split off or appear in any position other than the position immediately next to the verb. ${ }^{7}$

(28) a. János ma be-számít-ható.

János today PART-count-ABLE

'János is sane today.'

b. *JÁnos számít-ható ma be.

János count-ABLE today PART

'It is János who is sane today.' (intended meaning)

c. *János nem számít-ható ma be.

János not count-ABLE today PART

'János is not sane.' (intended meaning)

These facts, in sharp contrast with those presented in (27) argue for a syntactic difference between the two types of examples, a difference that is completely in line with the predictions of our analysis that assigns the ható form in (28) lexical status, and that of (27) a syntactic one.

${ }^{7}$ The same kind of difference with respect to negation can be attested in ható forms that appear as prenominal modifiers of nouns. With ható participles, the particle can be separated from the verb and be placed before negation for many speakers (i), while the same is completely impossible with ható adjectives (ii):

(i) az [ezzel a feladattal meg nem bíz-ható] emberek

the this.InsT the task.INST PART not trust-ABLE people

'the people who are not trustable with this task'

(ii) *a be nem számít-ható emberek

the PART not count-ABLE people

'people who are not sane' 
In (28), the putative particle be is a subpart of the lexical word beszámitható, and as such its position cannot be manipulated by any syntactic means, in line with the lexical integrity or word structure autonomy condition (Selkirk 1982; Booij 1985) that rules out manipulation of the internal parts of lexical items. The position of the particle in the ható clause in (27), on the other hand, is susceptible to syntactic manipulation just like it is in finite clauses, exactly because the ható form is not a frozen lexical unit. The fact that the particle positions are the same as in finite clauses provides evidence that these ható constructions are not lexically derived, but put together in the syntax.

The same kind of argument can also be made with reference to another syntactic process, ellipsis. One of the forms of clausal or TP ellipsis in Hungarian affects the tensed domain of the finite clause in positive answers to a polar question (see also Holmberg 2001 for TP ellipsis of this general type). As (29B) shows, the answer to a yes/no question can solely consist of the particle:
A: Meg bíztad Jánost a feladattal?
PART entrusted.2SG János.ACC the task.INST
'Did you entrust János with the task?'
B: Meg.
PART
'I did.'

As was shown in Lipták $(2012 ; 2013)$, in this process of particle-stranding the answer in (29B) is an instance of forward constituent ellipsis, and contains the entire TP elided after the particle (together with the verbal head). The only item not affected by ellipsis is the particle, which moves to a focal position in the left periphery and thus survives TP ellipsis - providing another piece of evidence for the syntactic autonomy of the particle:

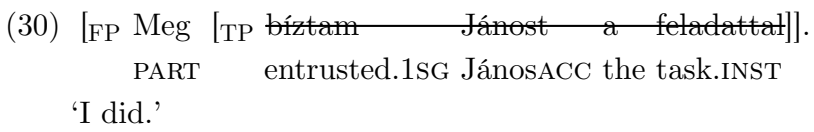

It is interesting that the exact same kind of particle placement as found in (30) can be observed in ható clauses as well. When ható forms are used as main predicates of the clause, the particle associated with the base verb can be left behind in positive answers to polar questions. In other words, 
ellipsis eliminates the tensed domain together with the main predicate, but to the exclusion of the particle: ${ }^{8}$

${ }^{8}$ It is crucial to stress that the above demonstrated ellipsis process in (29) is ordinary forward ellipsis deleting an entire clause to the exclusion of a single constituent (the particle), the type of ellipsis that is standardly taken to be a clausal reduction operation (Merchant 2001, among others). This process elides syntactic constituents and is subject to the same recoverability conditions as for example fragment formation, cf. (i), where ellipsis is made possible by the fact that the elliptical remnant is manipulated by the syntax and comes to occupy a position outside the elided constituent.

(i) A: JÁNost bízta meg a feladattal?

János.ACC entrusted.3SG PART the task.INST

'Was it János who she entrusted with the task?'

B: [FP JÁNOST [TP brzta a delatald]].

János.ACC entrusted.3SG PART the task.INST

'János (it was).'

Note also that this process is clearly distinct from coordination-based so-called wordpart ellipsis (also called conjunction reduction) in which part of a (compound) word or phrase undergoes ellipsis. Word-part ellipsis can elide the verb to the exclusion of its particle in Hungarian, cf. (ii) (Bánréti 2007; Kenesei 2007; 2008), just as it can apply in similar contexts in other languages (cf. Hungarian (a) to the Dutch (b)):

(ii) a. $\mathrm{ki}$ és be-vonul out march.3sG and in-march.3sG

b. in topen en uit-lopen (Dutch)

in walk.INF and out-walk.INF

As Booij (1985) argued, word-part ellipsis is not a syntactic operation, but a prosodic one, and as such it does not violate lexical integrity (see Booij 1985). Evidence for its prosodic nature comes from the fact that it does not observe syntactic constituency: the elided material need not correspond to a syntactic constituent (indicated by brackets), rather prosodic ones (see also Kenesei 2007; 2008):

(iii) [[ki ellenes] és be-vonulás ellenes

out march.NOM opposed and in-march.NOM opposed

'opposed to marching in and out'

For this reason, in this section arguing for the syntactic derivation of some ható forms, we do not base our arguments from ellipsis on operations like word-part ellipsis, but rather the ellipsis of particle-stranding in (29). That particle-stranding is unlike wordpart ellipsis is also evident from that fact that (a) it is not coordination-based (rather it operates across utterance boundaries), and (b) it is an instance of forward ellipsis, while word-part ellipsis is necessarily backward, observe the ungrammaticality of the following example attempting to eliminate material in the second conjunct:

(iv) *ki vonulás ellenes és be-llenes

out march.NOM opposed and in-march.NOM opposed

'opposed to marching in and out' 
(31) a. A: Meg bíz-ható János a feladattal? PART entrust-ABLE János the task.INST

'Is János entrustable with the task?'

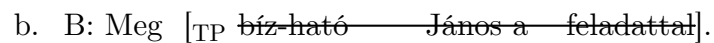

PART entrust-ABLE János the task.INST

'He is.'

Importantly, and predictably by now, lexical ható adjectives do not allow for the splitting up of the ható word in the same way. In these cases the particle cannot function as an answer to the question. In (32a), this is shown for the case of beszámitható and in $(32 \mathrm{~b})$, this is shown for the adjective megbizható characterized by an individual level reading (see (20a) above). ${ }^{9}$

(32) a. A: Be-számít-ható ma János?

PART-count-ABLE today János

'Is János sane today?'

B: *Be [TP számít-há ma János].

PART count-ABLE today János

'He is.'

b. A: Meg-bíz-ható-bb János mint Mari?

PART-trust-ABLE-COMP János than Mari

'Is János more trustable than Mari?'

B: *Meg [те b́z-há́-bb Janos mint Mari].

PART trust-ABLE-COMP János than Mari

'He is.'

The possibility of ellipsis of the base verb plus ható in the case of ható clauses in (31) thus provides further evidence for the syntactic derivation of these clauses. Only a syntactic derivation of the ható phrase yields the

${ }^{9}$ The only correct positive reply in this case repeats the entire adjective, as in (i). This non-splitting strategy is available for all adjectives and non-verbal predicates in general (cf. (ii)):

(i) A: Be-számít-ható ma János? B: Beszámítható.

PART-count-ABLE today J. PART-count-ABLE

'Is János sane today?'

'He is.'

(ii) A: Beteg ma János? B: Beteg.

ill today J. ill

'Is János ill today?' 'He is.' 
kind of syntactic autonomy of the particle that is observed in finite clauses: one in which the particle freely moves out of the tensed domain. On the other hand, ható adjectives exhibit no such autonomy of the particle due to the fact that these adjectives are lexical words whose internal structure is an opaque domain for syntactic processes like clausal ellipsis.

\section{A morpho-phonological difference: variation in the linking vowel in plural affixation}

The two classes of ható forms we have established show a distinction in the domain of morphophonology as well. This distinction is present in the form of the plural marker that is found on ható forms when they are used predicatively.

To introduce this morphophonological distinction, we first have to note that adjectival and nominal predicates in Hungarian agree with their subject in number, cf. (33).

(33) Ezek a lány-ok szép-ek.

these the girl-PL beautiful-PL

'These girls are beautiful.'

The plural marker on the predicate adjective $-e k$ consists of the plural marker $-k$ and a so-called linking vowel, $-e$ in this case, the latter harmonizing with the vowel quality of the adjectival stem.

As Kálmán et al. (2012) have shown, adjectival forms (both derived and underived) ending in -ó/ó, show variation in the presence of the linking vowel: most speakers find the linking vowel optional (with some individual preferences detectable):

(34) Ezek a lány-ok méltó $\{-\mathrm{k} /-\mathrm{ak}\}$ a díjra.

these the girl-PL worthy-PL the prize.suB

'These girls are worthy of the prize.'

In an on-line survey carried out in May 2013 with 34 informants, we tested the presence of the linking vowel in forms ending in hato (since they also end in $-o /-o ́)$. We have found that the use of the linking vowel is sensitive to the nature of the ható form, lining up according to the split we are arguing for in this paper: ható adjectives show the same variation with respect to the use of the linking vowel as ordinary adjectives, but ható clauses do not. 
While most speakers find the linking vowel optional with ható adjectives (again, with some individual preferences detectable), speakers systematically disprefer the linking vowel with ható clauses:

(35) A piros színú gombá-k nem ehetô\{-k/-ek\}.

the red colored mushroom-PL not edible-PL

'Red mushrooms are not edible.'

(36) A 10 évesnél régebbi használt autók nem számítható $\left\{-\mathrm{k} /{ }^{? *}\right.$-ak $\}$ be he 10 year.than older used cars not countable-PL PART egy új autó árába.

a new car price.POSS.3SG.ILL

'Cars older than 10 years cannot be counted toward the price of the new car.'

Interestingly, this behaviour is entirely parallel to the behaviour of present participial clauses. Lexicalized forms show variation in the presence of the linking vowel, while clausal participials do not use a linking vowel at all:

(37) (Sok diák volt a teremben.) A kivál-ó\{-k/-ak\} jutalmat kaptak. many student was the room-in the outstand-PR.PRT-PL prize.ACC received '(Many students were in the room.) The excellent ones received a prize.'

(38) (Sok diák állt a téren.) A tömegból kivál-ó\{-k/*-ak\} hazasétáltak. many student stood the square.ON the crowd.From outstand-PR.PRT-PL home.walked 'Many students stood on the square. The ones separating off the crowd walked home.'

This shows that the morphophonological form of the plural marker $-k$ is sensitive not only to the phonological shape of the final syllable, but also to the category of the ható form. It transpires that ható clauses cannot appear with a linking vowel, while ható adjectives optionally can.

\section{The structure of ható participles}

In this section, we turn to the analysis of participial ható, with an aim to provide a representation for it that appropriately reflects its morphological and basic syntactic composition. We also aim to place the proposed structural analysis in a cross-linguistic light by observing patterns from other languages that are similar in some way to Hungarian and thus may count as support for our analysis.

As we mentioned above in section 2, we take both adjectival and clausal ható forms to contain the same inflectional element, ható. We fur- 
thermore treat ható (following suggestions in Komlósy 1992, 395; Kiefer 1998, 252) as a complex unit that contains two subparts: the potential -hat morpheme (also inflectional in nature, see Kenesei 1996; Bartos 2000) and the present participle morpheme -ó 'PR.PRT', which derives nonfinite clauses (39):

(39) a könyvet a gyerekeknek ad-ó férfi

the book.ACC the children.DAT give-PR.PRT man

'the man giving the book to the children'

The morpheme - hat that appears in combination with the -ó ending requires more comments. This - hat is homophonous with the active potential -hat morpheme that can attach to any verb in Hungarian, transitive and intransitive alike. This active potential affix can have an epistemic or a root modality reading. We illustrate these in (40).

(40) a. A férfi a gyerekeknek ad-hat-ja

a könyvet.

the man the children.DAT give-POT ${ }_{\mathrm{ACT}}$-DEF.3SG the book.ACC

'The man is allowed to give the book to the children.'

'It may be the case that the man gives the book to the children.'

b. A férfi sétál-hat- $\emptyset$.

the man walk-POT ${ }_{\mathrm{ACT}}$-INDEF.3SG

'The man is allowed to walk.'

'It may be the case that the man walks.'

Albeit homophonous with it, the -hat morpheme that yields ható together with the participial ending -ó is different from the active potential affix with respect to two important properties: its specification for Voice (see section 5.1.) and the kind of modality expressed by it (see section 5.2.). Due to these differences, we do not equate the two homophonous forms, and we refer to the - hat morpheme in ható as the passive potential modality affix, to distinguish it from its active homophone. ${ }^{10}$

${ }^{10}$ It is this aspect of the analysis in which we differ most from previous discussions of ható in the generative literature, as discussed in Komlósy (1992); Kiefer (1998) and Bartos (2000). These works consider the question of whether ható can be decomposed into -hat and -o, and conclude that such decomposition cannot account for the passive component of meaning, as neither (what we call) active -hat nor -ó are passivizing morphemes themselves. If, however, we treat the affix -hat in -ható as a passive - hat, distinct from the active - hat in (40), decomposition is possible.

At the same time, we do not rule out the option that the passive and the active -hat morphemes have developed out of a single potential element that was underspecified in that it could appear on both active and passive verb forms. We are aware 


\subsection{The passive component}

We begin the discussion with ható's specification for Voice. In present-day Hungarian, ható only attaches to passive (and thus necessarily transitive) predicates, whose external argument has been demoted.

(41) a. a gyerekeknek ad-hat-ó könyv

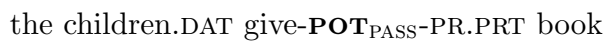
'the book that can be given to the children'

b. Ez a könyv gyerekeknek ad-hat-ó. this the book children.DAT give-POT ${ }_{\text {PASS }}$-PR.PRT lit. 'This book is givable to children.'

The passive verb form that serves as the base of the derivation is unmarked, that is, it contains no overt passive morpheme (it is important to add that Hungarian does not have passive finite clauses either, the morphological passive being obsolete now). The presence of the covert passive morpheme

that the use of ható on unaccusative verbs, ungrammatical in present day Hungarian, is attested in the recent history of the language as late as in 19th century, as the following examples illustrate.

(i) a. A tisztaszobában ágy is volt vetve, the guest.room.INE bed also was made érkez-hetô tisztes vendég számára. arrive-ABLE respectful guest for

'There was a bed prepared in the guest room for respectful guests that might arrive.'

(Mór Jókai, Mégis mozog a föld, 1872)

b. Erre a meg-es-hetô szerencsétlenségre nem is gondolt. this.sub the PART-happen-ABLE mishap.SUB not also thought.3SG

'He didn't even think about this mishap that might happen.'

c. [...] és egy ollyat adni a' gondolkodni szeretók and one such.ACC give.INF the think.INF love.PR-PRT.PL kezébe, melly minden elő-fordul-ható esetnél hand.POSS3SG.INE which all PART-occur-ABLE case.ADE utba igazítsa öket... way.INE guide them '[...] and to give something into the hands of those who like to think, which can guide them in every case that might occur.' (Zsigmond Ferenczy, Adalék honi nyelvünk és irodalmunk történetéhez, 1844)

This indicates that the addition of the passive ingredient to the potential -hat morpheme in ható forms might be a relatively recent development in the language. 
in ható participles, however, is supported by various pieces of evidence. First, the passive nature of ható participles is shown by the fact that the demoted agent that optionally appears in ható participles carries the same oblique marker (postposition) as it does in the passive ( $a k a$ past) participle constructions, namely, által 'by', see (13b), repeated here as (42a).

(42) a. Ez a program bárki által letölt-het-ô.

this the program anyone by download-POT ${ }_{\mathrm{PASS}}-\mathrm{PR} . \mathrm{PRT}$

'This program can be downloaded by anyone.'

b. egy Péter által letölt-ött program

an Péter by download-PASS.PRT program

'a program downloaded by Péter'

Second, there are a handful of transitive verbs in Hungarian that cannot appear in the passive, i.e., do not have a passive participial form. The same set of verbs cannot form a ható participle, either, which can be explained if ható participles are passive in nature:

(43) a. Péter el-vette

Zsuzsát.

Péter PART-married.DEF3SG Zsuzsa.ACC

'Péter married Zsuzsa.'

b. ${ }^{*}$ az $\{$ el-ve-tt/ el-ve-hető $\} \quad$ lányok

the PART-marry-PASS.PRT PART-marry-POT ${ }_{\text {PASS-PR.PRT girls }}$

intended meaning: 'the girls who were married/who can be married'

(44) a. Péter kétli az eredmények érvényességét.

Péter doubt.DEF3SG the result.PL validity.POSS3PL.ACC

'Péter doubts the validity of the results.'

b. $*$ knétel-t/ kétel-het-ô $\} \quad$ érvényesség

doubt.PASS.PRT doubt-POT PASS-PR.PRT validity

lit. 'doubted validity'

Third, that ható participles contain a passive ingredient is also in line with the observation in the cross-linguistic literature that -able type adjectives are built on passive forms, see Anagnostopoulou \& Samioti (2014) and Oltra-Massuet (2014) and references cited in the latter (such as Chapin 1967; Fabb 1984 among others, as well as Kayne 1981 on a related point). The morphological composition of -able forms in many languages reflect this fact. As Oltra-Massuet (2014) points out, in Turkish the complex verbal suffix $\operatorname{Il}(y) A b i l(A) r$ or $(I) n(y) A b i l(A) r$, corresponding to -able in 
English, contains both a passive and a modality affix, providing the most striking evidence for the claim that -able forms are internally complex.
(45) $\mathrm{Bu}$ oku-n-abil-ir bir kitap.
this read-PASS-MOD-AOR a book
'This is a readable book.'

In Japanese, the same meaning is carried by a form that only contains an overt passive morpheme and lacks an ability modal. As illustrated in (46), Japanese passive potentials contain the run-of-the-mill passive morpheme in potentials expressing the same meaning as ható potentials in Hungarian, as Ishizuka and Koopman (2014) show.

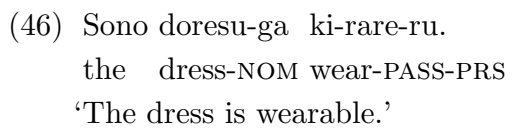

(46) Sono doresu-ga ki-rare-ru.

the dress-NOM wear-PASS-PRS

'The dress is wearable.'

On the basis of these facts it seems clear that able/ható forms are built on a passive construction, and languages might differ in whether they morphologically spell out the passivizer (Japanese), the modal affix (Hungarian) or both affixes (Turkish).

The close connection between -able forms and the passive is also revealed in other languages. Bantu languages provide evidence that passive and potential ability can be expressed via the same morphological means: the potential ability reading and the stative passive meaning receive the same expression, cf. the -IK morpheme in Chichewa (data from Dubinsky \& Simango 1996, see for the same observation Chavula 2016 for Citumbuka and Seidl \& Dimitriadis 2003 for Swahili). ${ }^{11}$

${ }^{11}$ Russian is similar to Bantu, as present passive participles, derived by adding - im/em and an adjectival ending to the verb stem can express both a passive and an ability reading, the latter usually in the negative form, prefixed by ne- (Lena Karvovskaya p.c.). See Petrova (2008) for the relation between the passive participle and the adjectival forms.

(i) Perevod-im-aja statja dolzhna polnostju soxranit pervonachalnyj smysl. translate-IM-ADJ.F paper must complete keep original meaning

'The paper that is being translated must keep its original meaning.'

(ii) Eto ne-perevod-im-aja igra slov.

this not.translate-IM-ADJ.F game.NOM word.GEN.PL

'This is an untranslatable word game.' 
(47) Nyemba zi-na-li zo-phik-ida.

beans ARG-PAST-be AGR-cook-IK

'The beans were cooked.' /'The beans were cookable.'

Having established the passive nature of ható participals in Hungarian, we are in position to draw up a basic syntactic representation of their composition. To indicate this voice-specific selectional property of passive potential -hat, we argue that the modality potential -hat selects a passive verb phrase (a VoiceP) as its complement, cf. (48) as the structural representation of (41a).
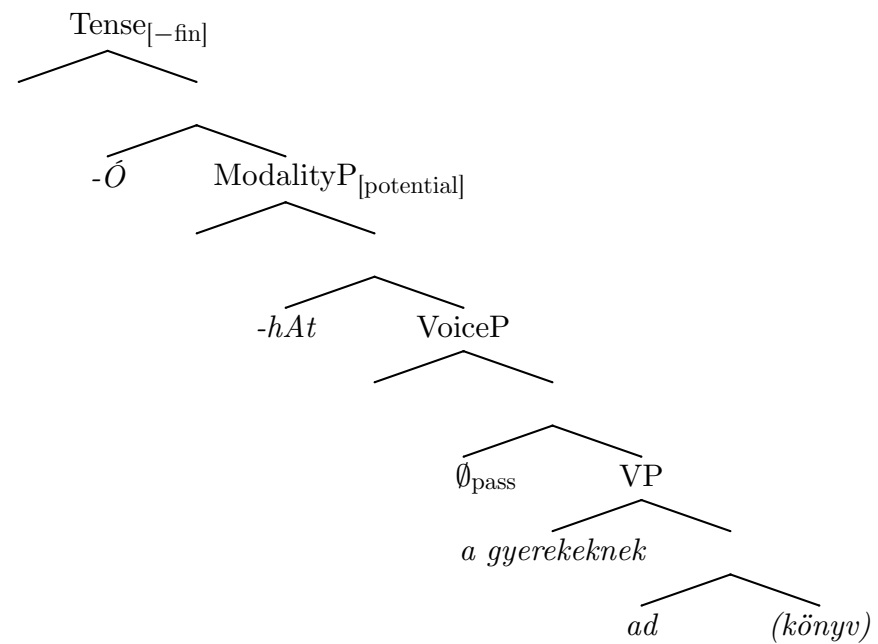

There are two reasons behind proposing that passivization applies to the verb phrase, and it does so before potential modality builds in, even though the passivization operation is morphologically unmarked in Hungarian and thus its place vis-à-vis other morphemes cannot be established. One is that the proposed order is in line with the universal order of positions in the extended projection of the verb (see Kratzer 1996, among many others). Second, we fashion our analysis on the basis of Ishizuka and Koopman (2014), who argue that -rare (cf. (46)) appears in a VoiceP below the modality phrase.

The difference between Hungarian and Japanese then boils down to the realization of these functional projections: while in Hungarian the potential affix is overt and the passive one is null, Japanese shows the reverse. In a similar approach, Turkish would have both of them overt, thus filling in the remaining slot, as it were, in a three-way variation of the morphology 
of passive potentials. Russian and the Bantu languages follow the Japanese pattern, while English -able is like Hungarian ható in this respect.

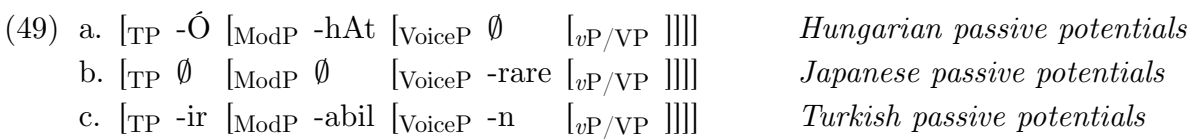

\subsection{Root modality and intentional reading}

Having discussed the position of the passive -hat morpheme, we turn to the second point of difference between active and passive -hat morphemes, which concerns interpretation: while active -hat can express a variety of meanings, including an epistemic one (see Kiefer 1981 for an overview), passive -hat can only express dispositional (root) modality and lacks the epistemic reading: ${ }^{12}$

(50) A férfi a gyerekeknek ad-hat-ta a könyvet.

the man the children.DAT give-POT ${ }_{\mathrm{ACT}}$-PST.3SG the book.ACC

'It may be the case that the man gave the book to the children.'

'The man was allowed to give the book to the children.'

(51) Ez a könyv gyerekeknek ad-hat-ó volt.

this the book children.DAT give-POT PASs $_{\text {-PR.PRT was }}$

\#'It might be the case that this book was given to the children.'

lit. 'This book was givable to children.'

The fact that -hat in -ható expresses dispositional (root) modality arguably also explains why the passive -hat morpheme implies that the base predicate must be understood with the semantic ingredient of obligatory intentionality, i.e., requiring that the expressed event has an agentive initiator, who has to make an effort to reach the resulting state described by the passive (Toman 1987).
a. A szél szét-hord-hat-ja
a szemetet.
the wind PART-carry-POT ${ }_{\mathrm{ACT}}$-DEF.3SG the trash.ACC
'The wind can scatter the trash.'

12 The epistemic reading with ható can possibly be missing as the epistemic operator cannot scope out of the participial clause and take scope over the finite tense (representing the truth value of the sentence). In finite contexts, such scopal relations are possible as Bartos (2000) has shown. 
b. A szemét szét-hord-hat-ó.

the trash PART-carry-POT ${ }_{\text {PASS-PR.PRT }}$

'The trash can be scattered (by someone doing something to it/by the wind).'

(53) a. Egy földrengés el-pusztít-hat-ja a várost.

an earthquake PART-destroy-POT ${ }_{\mathrm{ACT}}$-DEF.3SG the city.ACC

'An earthquake can destroy the city.'

b. A város el-pusztít-hat-ó.

the city PART-destroy-POTPASS-PR.PRT

'The city can be destroyed (by people doing something to it/*by an earthquake).'

We believe this meaning ingredient stems from the fact that the passive potential affix expresses root modality, as root modality is known to be an agentive type of modality. Note also that this meaning ingredient cannot originate from these forms containing passive voice: passive participles do not imply agentive activity resulting in the state described by the passive.

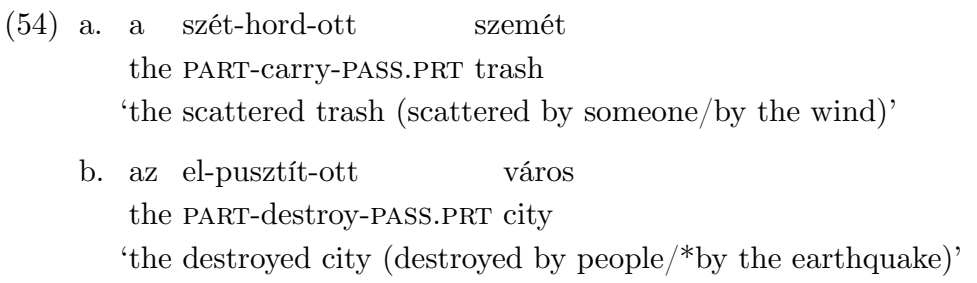

\subsection{On the position of the internal argument in ható participials}

Before concluding this section, we must return to the question how the internal argument of the base verb in ható participial clauses is case-licensed. As we have indicated in (48), this argument thematically originates in the complement position inside the VP, but as a result of passivization it is promoted to subject.

This promoted argument always appears outside the participial clause as the subject predicated about by the participial clause or the noun phrase modified by the participle. Its position outside the participial clause is related to case-licensing. Due to the fact that the ható participle is a nonfinite form, it cannot assign nominative case to this argument and for this reason, the promoted subject must invariantly receive case elsewhere, outside the participle.

When ható participles function as main predicates in their clause, they must be embedded under a copula, and the internal argument receives case 
in the finite clause containing the copula (cf. (55a)). When the participial is a prenominal modifier, the promoted internal argument receives case in function of its position as a nominal constituent in its clause (cf. (55b)).

(55) a. $\left[\mathrm{TP}(+\right.$ fin $)$ Ez a könyv ${ }_{i}$ nem volt $\left[\mathrm{TP}_{(- \text {fin) }}\right.$ gyerekeknek ad-hat-ó $\left.\left.\quad e_{i}\right]\right]$ this the book not was children.DAT give-POT ${ }_{\mathrm{PASS}}-\mathrm{PR} . \mathrm{PRT}$

lit. 'This book was not givable to children; This book could not be given to children.'

b. $\left[\right.$ TP(-fin) gyerekeknek ad-hat-ó $\left.\quad e_{i}\right]$ könyvek-et ${ }_{i}$ vettem. children.DAT give-POTPASS-PR.PRT book.PL-ACC bought.1SG

'I bought books that can be given to children.'

It is important to stress that the illustrations in (55) aim to reflect the thematic relatedness between the co-indexed elements. We are uncommitted as to the question of how the promoted internal argument gets to its participial-external position, via movement or other means (such as being base-generated outside the participial, with an empty operator binding its position inside the participial). What is important is that the predicative use of ható participles in (55) runs completely parallel to that of adverbial participles in Hungarian, such as the adverbial $-v A$ participles (also called the pseudopassive as it is used instead of the by now obsolete morphological passive), which also need to combine with the copula to be used as main predicates, a combination that is motivated by the need to license case on the internal argument of the $-v A$ participle, as argued extensively in Bartos (2009).

(56) A levél nem volt meg-ír-va.

the letter not was PART-write-VA

'The letter was not written.'

Last but not least we need to mention that the complex ható ending is not the only productive element that has a passivizing component preceding the -ó participial ending in Hungarian. Another nonfinite ending that combines modal semantics (deontic modality) with passive voice is -andó (which again comes in two harmonizing forms: -andó/endó). ${ }^{13}$ The

${ }^{13}$ É. Kiss (2005) argues that in contrast with traditional views -andó has a modal rather than a temporal (future) meaning. Laczkó (2000, 441-444) shows that additional construction subtypes are acceptable in some dialects, in which unaccusatives can underlie the participle, while Dékány (2014, 224-227) presents a number of interesting, and now obsolete constructions from Old Hungarian, in which unergatives, too, served as the root of the construction. 
verb forms constructed via this suffix can be used both attributively (57a) and predicatively $(57 \mathrm{~b})$, and when the latter, the verbal particle can be removed from them. In both uses arguments of the base verb must be

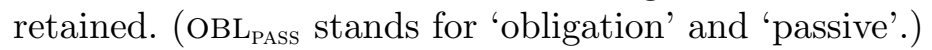

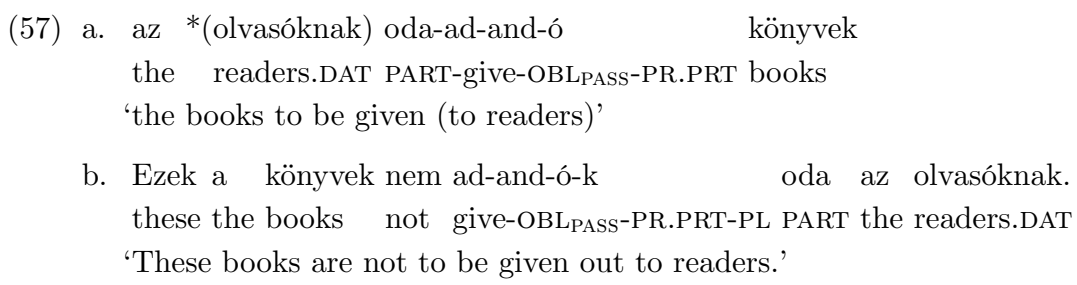

Moreover, idiosyncratic lexicalized forms, i.e., true adjectives, also occur in

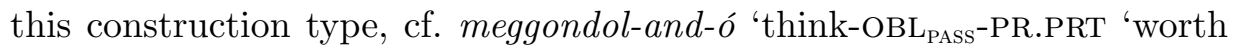
thinking about', megvet-end-ó 'despise-OBL $\mathrm{PASS}_{\mathrm{PA}}$-PR.PRT, to be despised, despicable'. Unlike the participial forms in (57), lexicalized adjectives can have comparative and superlative forms, as well as be preceded by intensifiers.

\section{Summary of findings}

This paper offers novel evidence that the seemingly derivational affix ható does not apply in the lexicon and does not directly produce canonical adjectives in Hungarian. So rather than considering it as an adjectivalizer affix, it is best classified as a purely syntactic device producing nonfinite clauses.

We have provided several arguments for this claim. The first came from category-specific tests, with which we have shown that while some ható words are proper adjectives, a great number of ható forms are not. On the basis of this we have argued that those forms that are not adjectival are formed in the syntax: the ható affix applies to a verb phrase, and the resulting nonfinite clause inherits the base verb's argument and event structure. On the other hand, ható adjectives differ from ható clauses in that they are lexicalized as adjectives and consequently behave as lexical units. Key evidence for the lexicalized nature of these adjectives were presented from the placement of particles belonging to ható forms in syntactic configurations that trigger the splitting off of the particle from the base verb in for example finite clauses. This kind of splitting is possible only in the case of ható clauses, but not in the case of ható adjectives. Last but not least, we have shown that speakers distinguish between lexical vs. non-lex- 
ical ható forms when it comes to the plural marker that these receive: the distinction boils down to the use of the linking vowel before the plural $-k$ marker in the lexical cases only. Table 3 lists all distinctive properties of the two types of ható at a glance.

Table 3: Summary of findings

\begin{tabular}{llcc}
\hline Properties of ható forms & ható adjectives & ható clauses \\
\hline (i) & modification by intensifiers or adverbs & intensifiers & adverbs \\
(ii) & input to lexical derivations & $\checkmark$ & $*$ \\
(iii) & availability of comparative forms & $\checkmark$ & $*$ \\
(iv) & non-compositional meaning possible & $\checkmark$ & $*$ \\
(v) & argument and event structure present & $*$ & $\checkmark$ \\
(vi) & stage vs. individual level reading & stage/individual level & stage level \\
(vii) & PART can split off the verb under focus/ & $*$ & $\checkmark$ \\
& negation/ellipsis & $-k$ or $-V k$ & $-k$ \\
(viii) & plural form
\end{tabular}

In addition the initial survey of the exponents of the passive potential morpheme across languages holds promise of a comprehensive typology of the variation in its exponents.

\section{Acknowledgements}

We owe our thanks to audiences at the Research Institute for Linguistics (October 2013, Budapest), and the 16th International Morphology Meeting 16 (May 2014, Budapest), as well as reviewers from Journal of Linguistics, Word Structure, and Acta Linguistica Academica. The first author's work is supported by the Vrije Competitie grant "Ellipsis licensing beyond syntax" by NWO (Netherlands Organisation for Scientific Research). The second author's work was supported by a grant from the Hungarian National Research Fund, OTKA N 100804 "Comprehensive Grammar Resources: Hungarian".

\section{References}

Anagnostopoulou, Elena and Yota Samioti. 2014. Domains within words and their meanings: a case study. In A. Alexiadou, H. Borer and F. Schäfer (eds.) The syntax of roots and the roots of syntax. Oxford: Oxford University Press. 81-111.

Bánréti, Zoltán. 2007. A mellérendelés és az ellipszis nyelvtana a magyarban [The grammar of subordination and ellipsis in Hungarian]. Budapest: Tinta Könyvkiadó.

Bartos, Huba. 2000. Az inflexiós jelenségek szintaktikai háttere [Syntactic background of inflectional phenomena]. In Kiefer (2000, 653-762). 
Bartos, Huba. 2009. The syntax of Hungarian -va adverbial pariticiples: A single affix with variable merge-in locations. In É. Kiss (2009, 75-102).

Bartos, Huba. 2011. Hungarian external causatives: Monoclausal but bi-eventive. In T. Laczkó and C. O. Ringen (eds.) Approaches to Hungarian 12: Papers from the 2009 Debrecen conference. Amsterdam \& Philadelphia: John Benjamins. 1-38.

Bauer, Laurie. 1983. English word-formation. Cambridge: Cambridge University Press.

Booij, Geert. 1985. Coordination reduction in complex words: A case for prosodic phonology. In H. van der Hulst and N. Smith (eds.) Advances in nonlinear phonology. Dordrecht: Foris. 143-160.

Brinton, Laurel J. and Elizabeth Closs Traugott. 2005. Lexicalization and language change. Cambridge: Cambridge University Press.

Chapin, Paul. 1967. On the syntax of word-formation in English. Doctoral dissertation. MIT.

Chavula, Jean Josephine. 2016. Verbal derivation and valency in Citumbuka. Utrecht: LOT.

Dékány, Éva. 2014. A nem véges alárendelés (az igenevek) története [The history of nonfinite clauses]. In K. É. Kiss (ed.) Magyar generatív törteneti mondattan [Hungarian generative historical grammar]. Budapest: Akadémiai Kiadó. 177-238.

Dubinsky, Stanley and Silvester R. Simango. 1996. Passive and stative in Chichewa. Language 72. 749-781.

É. Kiss, Katalin. 2005. Az ómagyar igeidôrendszer morfoszintaxisáról [On the morphosyntax of the Old Hungarian tense system]. Magyar Nyelv 101. 420-435.

É. Kiss, Katalin (ed.). 2009. Adverbs and adverbial adjuncts at the interfaces (Interface explorations 20). Berlin \& New York: Mouton de Gruyter.

Fabb, Nigel. 1984. Syntactic affixation. Doctoral dissertation. MIT.

Farkas, Judit. 2013. Az ige analógiájára múködő -ható és -andó konstrukciók [-ható and/or -andó constructions in analogy to verbs]. In E. Kádár and S. Szilágyi N. (eds.) Analógia és modern nyelvleírás. A magyar nyelvészeti kutatások újabb eredményei III [Analogy and modern grammatical description: New results of Hungarian linguistic research III]. Kolozsvár: Erdélyi Múzeum-Egyesület. 51-62.

Halle, Morris and Alec Marantz. 1993. Distributed morphology and the pieces of inflection. In K. Hale and S. J. Keyser (eds.) The view from building 20. Essays in linguistics in honor of Sylvain Bromberger. Cambridge, MA: MIT Press. 111-176.

H. Tóth, Tibor. 2000. Észrevehetők/észrevehetôek vagy nem vehetők észre? Magyar Nyelv 96. 82-89.

Holmberg, Anders. 2001. The syntax of yes and no in Finnish. Studia Linguistica 55. $141-175$.

Ishizuka, Tomoko and Hilda Koopman. 2014. On the importance of being silent or pronounced: English -able and Japanese -rare potentials compared. Poster presented at GLOW 2014, HUB Brussel, 2-4 April 2014.

Kálmán, László, Péter Rebrus and Miklós Törkenczy. 2012. Possible and impossible variation in Hungarian. In F. Kiefer, P. Siptár and M. Ladányi (eds.) Current issues in morphological theory: (Ir)Regularity, analogy and frequency. Amsterdam \& Philadelphia: John Benjamins. 23-49.

Kayne, Richard S. 1981. Unambiguous paths. In R. May and J. Koster (eds.) Levels of syntactic representation. Dordrecht: Foris. 143-183. 
Kenesei, István. 1989. Logikus-e a magyar szórend? [Is Hungarian word order logical?]. Általános Nyelvészeti Tanulmányok 17. 105-152.

Kenesei, István. 1996. Képző vagy nem képző? [Derivation or inflection?]. In I. Terts (ed.) Nyelv, nyelvész, társadalom: Emlékkönyv Szépe György 65. születésnapjára barátaitól, kollégáitól, tanítványaitól, II. kötet [Language, linguists, society: Festschrift on the occasion of the 65th birthday of György Szépe from his friends, colleagues and students, volume 2]. Pécs: JPTE. 92-95.

Kenesei, István. 2007. Semiwords and affixoids: The territory between word and affix. Acta Linguistica Hungarica 54. 263-293.

Kenesei, István. 2008. Az ellipszis szabályai a szóösszetételekben [Rules for ellipsis in compounds]. In K. Bibok (ed.) A morfológiától a pragmatikáig: Tanulmányok Pete István 80. születésnapjára [From morphology to pragmatics: Festschrift for István Pete's 80th birthday]. Szeged: JATEPress. 63-77.

Kenesei, István. 2014. On a multifunctional derivational affix: Its use in relational adjectives or nominal modification, and phrasal affixation in Hungarian. Word Structure 7. $214-239$

Kiefer, Ferenc. 1981. What is possible in Hungarian? Acta Linguistica Hungarica 31. $147-185$

Kiefer, Ferenc. 1998. Alaktan [Morphology]. In K. É. Kiss, F. Kiefer and P. Siptár Új magyar nyelvtan [A new Hungarian grammar]. Budapest: Osiris Kiadó. 187-290.

Kiefer, Ferenc (ed.). 2000. Strukturális magyar nyelvtan 3. Morfológia [A structural grammar of Hungarian 3. Morphology]. Budapest: Akadémiai Kiadó.

Komlósy, András. 1992. Régensek és vonzatok [Heads and complements]. In F. Kiefer (ed.) Strukturális magyar nyelvtan 1. Mondattan [A structural grammar of Hungarian 1. Syntax]. Budapest: Akadémiai Kiadó. 299-527.

Komlósy, András. 1994. Complements and adjuncts. In F. Kiefer and K. É. Kiss (eds.) The syntactic structure of Hungarian (Syntax and semantics 27). San Diego/New York: Academic Press. 91-178.

Koopman, Hilda and Anna Szabolcsi. 2000. Verbal complexes. Cambridge, MA: MIT Press.

Kratzer, Angelika. 1996. Severing the external argument from its verb. In J. Rooryck and L. Zaring (eds.) Phrase structure and the lexicon. Dordrecht: Kluwer. 109-137.

Laczkó, Tibor. 2000. A melléknévi és határozói igenévképzók [Participle forming suffixes]. In Kiefer (2000, 409-452).

Laczkó, Tibor. 2001. A comprehensive analysis of -ó/-ó, a multifunctional deverbal nominalizer in Hungarian. In I. Kenesei (ed.) Argument structure in Hungarian. Budapest: Akadémiai Kiadó. 13-49.

Laczkó, Tibor. 2008. On binding, empty categories, and morphosyntactic processes in "passive" participial constructions. In Ch. Piñón and Sz. Szentgyörgyi (eds.) Approaches to Hungarian 10: Papers from the Veszprém conference. Budapest: Akadémiai Kiadó. $103-126$.

Leeman, Danielle. 1992. Deux classes d'adjectifs en -ble. Langue Française 96. 45-63.

Lipták, Anikó. 2012. Verb-stranding ellipsis and verbal identity: The role of polarity focus. Linguistics in the Netherlands 29. 82-96.

Lipták, Anikó. 2013. The syntax of positive polarity in Hungarian: Evidence from ellipsis. Lingua 128. 72-94. 
Merchant, Jason. 2001. The syntax of silence. Oxford: Oxford University Press.

Oltra-Massuet, Isabel. 2014. Deverbal adjectives at the interface: A crosslinguistic investigation into the morphology. Syntax and semantics of -ble. Berlin \& New York: Mouton de Gruyter.

Petrova, N. Je. 2008. Otglagol'nye prilagatel'nye na -m- i stradatel'nye prichastija nastojashchego vremeni: Problemy differenciacii i vzaimodejstvija. Russkij jazyk v nauchnom osveshchenii 2008/2. 89-109.

Seidl, Amanda and Alexis Dimitriadis. 2003. Statives and reciprocal morphology in Swahili. In P. Sauzet and A. ZribiHertz (eds.) Typologie des langues d'afrique et universaux de la grammaire. Paris: L'Harmattan. 239-284.

Selkirk, Elizabeth O. 1982. The syntax of words (Linguistic Inquiry Monograph 7). Cambridge, MA: MIT Press.

Surányi, Balázs. 2009a. Locative particle and adverbial incorporation at the interfaces. In É. Kiss $(2009$, 39-74).

Surányi, Balázs. 2009b. Verbal particles inside and outside $v \mathrm{P}$. Acta Linguistica Hungarica 56. 201-249.

Toman, Jindřnich. 1987. Wortsyntax - Eine Diskussion ausgewählter Probleme deutscher Wortbildung. Tübingen: Neymeyer.

Traugott, Elizabeth Closs and Richard B. Dasher. 2002. Regularity in semantic change (2nd ed.). Cambridge: Cambridge University Press.

Wood, Jim and Einar F. Sigurðsson. 2014. Building deverbal ability adjectives in Icelandic. University of Pennsylvania Working Papers in Linguistics 20. 351-360. 